and they are not wanting in incentive. "What we do lack is the 'follow through' thoroughly to search out and master a problem in all its details, generalities, and side issues, before turning our attention to new problems. To minds teeming with ideas all clamouring for attention it is not easy to ignore the many that a few may receive fuller attention." How true this is may be seen by contrasting the methods pursued in German schools of chemistry, where a single conception is hunted to death, as it were, by the professor and his pack of collaborators, who follow it through innumerable ramifications, like a harried hare. It would constitute an interesting statistical exercise to determine the number of Ph.D.'s which have been created by chasing special ideas, with the professor as a whipper-in. Of course, the method is not without its advantages in the interests of knowledge, but its real educative value may be doubted, and it certainly does not conduce to develop any latent creative power in the student. It is more frequently directed to serve the interest of the professor than that of his pupils.

Another source of Germany's prestige arose from the comparative cheapness of printing and publication in that country. Struggling men of science eked out a meagre salary by compiling books which were readily accepted for publication on a narrow margin of profit. New serials and journals, and works of reference, were easily started, to find their way into university libraries and State-aided institutions throughout the world as more or less authoritative and indispensable. The output of scientific and technical literature, good, bad, and indifferent, was, in fact, prolific.

Dr. Nutting contends that alien students, university professors, and technical men working in Germany have aided greatly in building up her scientific prestige. These aliens, he calculates, represented fully io per cent. in each class"clear 'velvet' to her, and a corresponding loss to their own countries." The students came, he states, in about equal numbers from Russia, England, and the United States, with a few from Scandinavia, Switzerland, and Japan, but scarcely any French or other Latins. The inducements were easy matriculation and graduation, while fees and living expenses were very moderatebarely half those at Oxford or Cambridge. "The instruction itself was hardly worth any special effort, but it was accessible, and it differed from the home product."

German universities have in the past. drawn freely upon foreign countries for their instructors. It has been estimated that a third of the more noted German men of science were foreign-bornRussians, Dutch, and Swiss. These, for the most part, soon became Teutonised, and were thereafter regarded as Germans. The Jews, too, whom the typical Teuton regards as aliens, and secretly dislikes and despises, have contributed in no small measure to the fame of his universities.

German capitalists have always welcomed and been ready to exploit technical men of ability, no matter of what nationality, and a large proportion of the better-known German manufactures have originated in France, Italy, England, or America.

Such are the main factors which, in Dr. Nutting's opinion, have contributed to Germany's scientific and technical prestige. "Plagiarism and piracy," he asserts, "were common practices, and from personal knowledge I doubt whether a third of even the more eminent German scientists were free from this taint. Further, the work of foreigners was taught as the work of Germans in both literature and science. Neither fairy tale nor scientific discovery, if in an obscure publication, was safe from adoption as their own, while the misleading of the young student was easy and common."

Aliena optimum frui insania. American men of science have the wisdom to profit by the errors of the enemy. The war has taught them how to mobilise their man power and to organise their forces of productive achievement. They will, however, not take over that particular code of ethics or standard of literary and scientific morality and conduct by which modern Germany, in her too eager desire for wealth and power, has lowered herself in the estimation of the civilised world.

\section{CLEAN MILK.}

THE importance of clean milk, by which is meant a milk free from visible dirt and having a low bacterial content, has been recognised for many years, and various attempts have been made to improve the general milk supply. To a large extent these have failed owing to the conditions which have been supposed to be necessary to attain this end, involving considerable expenditure in reconstruction of buildings and extensive modifications in methods and plant-alterations which, setting aside cost, it is difficult to induce the average farmer and dairyman to adopt.

Recent work, however, has shown that by adopting comparatively simple methods, involving little monetary outlay and but slight modifications in manipulation, it is possible to produce a relatively clean milk vastly superior to that ordinarily supplied.

In a Bulletin (No. 642, 1918) published by the United States Department: of Agriculture Messrs. Ayers, Cook, and Clemmer show that it is possible for the average dairyman on the average farm to produce milk practically free from visible dirt and, when fresh, with a low bacterial content by the adoption of three simple factors. These are (I) the use of sterilised vessels, (2) clean cows with clean udders and teats, and (3) the small-top milking-pail. If the milk is to retain its low bacterial content for any time a fourth factor is necessary, viz. the keeping of the milk at as near a temperature of $50^{\circ} \mathrm{F}$. as possible. Each of the factors mentioned contributes something to the lowering of the dirt and bacterial content, as NO. $257 \mathrm{r}$, VOL. IO2] 
shown by the experimental results obtained, the experiments being conducted in many instances in barns which can only be described as filthy.

First, with regard to the small-top pail; this is a pail with a lid covering, say, two-thirds of the top of the pail. Using unsterilised pails without any other precaution, the open pail gave an average per cubic centimetre of 497,653 bacteria, while the small-top pail gave an average of 368,2 I 4 bacteria-a 25 per cent. reduction. With sterilised pails, under the same conditions, the numbers were 22,677 and 17,027 respectively, an enormous reduction by the additional precaution of using sterilised utensils. Washing of the udder and teats reduced the bacterial content of the milk by about 5o per cent. By a combination of these three factors it was possible to produce a milk containing only 2000-3000 bacteria per cubic centimetre even on farms which by any ordinary standard would be considered to be very unhygienic. The original cost of a small-top pail is little more than that of an ordinary open pail, and it is no more expensive or difficult to care for. Prof. Delépine, in a report (1918) to the Sub-Committee on Clean Milk of the Sanitary Committee of the Manchester City Council, arrives at much the same conclusions. He summarises the points requiring special attention as follows: (I) Cleanliness of the shippens, cows, milkers, utensils, and dairy-hands; (2) protection of milk against dirt during milking; (3) sterilisation of milk pails, churns, etc., and their protection against re-infection pending using; (4) protection of fresh milk against admixture with stale milk; (5) avoidance of straining through a common strainer; (6) avoidance of cooling by methods causing large surfaces of milk to be exposed to the air or to unsterilised surfaces; and (7) cooling of the milk by keeping churns in cold stores or places.

Prof. Delépine advocates the use of the smalltop pail or some similar device. He finds that pails, coolers, and churns cleaned with very pure cold and hot water, and apparently scrupulously clean, are still capable of imparting a large number of bacteria to the milk, and urges the importance of steam sterilisation of the utensils. This last condition is not so difficult to accomplish, even on the small farm, as might at first sight appear, for simple and inexpensive steam generators can be devised. With a small boiler holding six quarts of water, heated with a paraffin stove and boiling in six minutes, it is possible to sterilise at one time six two-gallon pails or cans in fifteen to twenty minutes. By ensuring clean cows and milkers, and the use of sterilised utensils and of the small-top pail or similar device, really clean milk with a very low bacterial content, and therefore with enhanced kecping qualities, can be produced without of necessity the expensive remodelling of cowsheds and premises, and with very little disturbance of the time-honoured routine of the ordinary farmer or dairyman on the average farm.

R. T. Hewlett.

\section{NOTES.}

Sir Napier Shaw has been elected a foreign member of the Reale Accademia dei Lincei of Rome.

We notice with much regret the announcement in the Times that Prof. E. C. Pickering, director of the Astronomical Observatory of Harvard College, died on February 3 at seventy-two years of age.

A SPECral general meeting of the Geological Society will be held on Wednesday, March 26 , to consider the resolution of the council of the society:--"That it is desirable to admit women as fellows of the society."

True Institution of Civil Engincers has elected upon its roll of distinguished honorary members Marshal Foch, O.M., Field-Marshal Sir Douglas Haig, K.T., and Admiral Viscount Jellicoe of 'Scapa, G.C.B., O.M.

TuE gold medal of the Royal Astronomical Society has been awarded by the council to M. Guillaume Bigourdan for his observations of nebulæ, carried on for about twenty-five years. It will be presented at the annual general meeting of the society on Friday, February 14.

AT the general monthly meeting of the members of the Royal Institution, held on February 3, a bequest of $300 l$. was reported from the late Dr. T. Lambert Mears, who was a member of the institution for fiftythree years, and a donation of 5ol. from "an old member" in celebration of his fiftieth year of membership.

WE learn that M. G. Grandidier has been appointed general secretary of the Société de Géographie of Paris in succession to the late Baron Hulot. Baron Hulot, who had been secretary of the society for more than twenty years, was an occasional contributor to the pages of La Géographic. One of his most important papers was a life of d'Entrecasteaux, which appeared in 1894 , and was the first complete biography of the explorer. M. Grandidier is well known for his researches in the exploration and geography of Madagascar.

The Royal Horticultural Society in its report for I918, which has just been issued, makes the important announcement that the revision of "Pritzel" is now in hand, and that the work of preparing it for the press is in progress at Kew under the personal supervision of Capt. A. W. Hill. It is estimated that the work will include about 250 ,000 references, and its cost of production will be at least $350 \mathrm{ol}$., towards which assistance is asked from the botanic stations, experimental stations, and libraries of the world as well as from private subscribers. All subscribers of I $_{5}$ guineas will reccive a free copy, and those of larger amounts a specially bound copy, according to their donation.

IT was announced by the president of the Royal College of Physicians on January 30 that the Swiney Prize, the award of which is adjudicated by a joint committee of the College and of the Royal Society of Arts, has been awarded to Dr. C. A. Mercier for his work on "Crime and Criminals." Dr. Raymond Crawfurd has been appointed to deliver the Harveian Oration of the College on St. Luke's Dav, October i8, Dr. A. P. Beddard to be Bradshaw Lecturer, and Dr. Aldo Castellani to be Milroy Lecturer for ig2o. Dr. J. McVail will deliver the Milroy lectures on "Smallpox and Vaccination since 1870 ," on March 13 , I8, and 20; I)r. Topley the Goulstonian lectures on the "Spread of Bacterial Infection," on March 25 and 27 and April I; and Sir H. D. Rolleston the Lumleian lectures on April 3, 8, and 1o, taking as his subject "Cerebrospinal Fever." 